Vol. 11 (4): 803-814 (2021)

\title{
OCCURRENCE OF HEAVY METALS IN BÜYÜK MENDERES RIVER BASIN, TURKEY
}

\author{
Ebru Çokay $^{1 *}$, Serkan Eker ${ }^{1}$, Ilgi Karapınar ${ }^{1}$, Erhan Şener $^{2}$ \\ ${ }^{I^{*}}$ Dokuz Eylül University, Department of Environmental Engineering, Tinaztepe Campus, \\ 35160 Buca-Izmir, Turkey; \\ ${ }^{2 *}$ Suleyman Demirel University, Department of Geological Engineering, 32260 Çünür-Isparta, Turkey; \\ "Corresponding Author Ebru Çokay, e--mail: ebru.cokay@deu.edu.tr;
}

Received June 2021; Accepted July 2021; Published August 2021;

DOI: https://doi.org/10.31407/ijees11.418

\begin{abstract}
The Büyük Menderes River, the one of the most important rivers in the Aegean side of Turkey serves as a resource for various water uses. Therefore, environmental quality of the Büyük Menderes River basin is a critic issue due to great pressure from a diverse range of humans and their activities. Heavy metals are one of the most known priority or special pollutants in aquatic ecosystem. The free metal ion is the most toxic form to aquatic life. Thus, determining the total concentration of a heavy metal in a water sample provides relative information about its toxicity. The European Union (EU) declared that metals as one of the most significant pollutants to be controlled and monitored in water bodies based on Water Framework Directive (WFD) that focuses on providing sustainable management of river, lake, transition, ground and coastal waters. The main objective of WFD is to achieve "good ecological and chemical status" to protect human health, water supply, natural ecosystems, and biodiversity. In this work, the detected heavy metal concentrations of 19 metals at 15 lakes, 2 transition, 4 coastal and 26 river-sampling stations of Büyük Menderes River Basin (BMRB) were monitored for a year according to EQS values. Monthly and annual average concentrations of heavy metals were evaluated, and the results were presented with environmental quality standards namely Annual Allowable Concentration (AA-EQS) and Maximum Allowable Concentration (MAC-EQS).
\end{abstract}

Keywords: Büyük Menderes River, Environmental Quality Standards, Metal Pollution, Water Framework Directive. 